\title{
The Nexus of Training, Employee Commitment and Employee Performance in Nepalese Commercial Banking Sector
}

\author{
Sajeeb Kumar Shrestha, PhD \\ Associate Professor, Tribhuvan University \\ Email: drsajeeb@gmail
}

\begin{abstract}
This research attempts to measure the nexus of training, employee commitment, and employee performance in the Nepalese commercial banking sector. Descriptive and causal research design is used to achieve the objectives of the research. Structured questionnaires were made, and the survey was done to collect primary cross-sectional data. Employees of the commercial banks in Kathmandu Valley who have been involved in the training program at least one time are included in the survey. Judgmental sampling was taken. This research confirmed that the training need assessment, mode of training, and training feedback significantly influence employee commitment, and employee commitment influences employee performance in commercial banks. So, bank managers must accept the nexus of training in employee commitment and employee performance.
\end{abstract}

Keywords: training, employee commitment, employee performance, PLS-SEM

\section{Introduction}

Training has been given in organizations from the beginning of organizations. An employee needs special capabilities and skills to perform the job. Vocational training was given to employees around a century ago under the organizations' research department (Salas \& Cannon-Bowers, 2001). Training equips employees with the knowledge, technology, and skills that enhance the employees' performance. Organizations implement training and management development programs for employees and managers to make human capital for improving the production of products and handling services (Black \& Lynch, 1996).

Elanga and Imran (2013) showed that training is a structured mechanism for developing the talents, knowledge, and skills of employees required to work efficiently on the job. Historically, training has been defined as how individuals change their skills, abilities, attitudes, and actions. In this sense, training involves creating and encouraging learning opportunities that contribute to the desired performance. On the other hand, training involves developing and promoting learning chances, which leads to performance expectations. Training is an instructional approach in which individuals can learn new 
concepts, relearn and develop existing knowledge and skills, and have time to think and discover what new alternatives can help them improve their effectiveness.

Organizations are always working under pressure to meet the challenges of globalization, technology change, changing political and economic business environment (Evans, Pucik, \& Barsoux, 2002). Evans et al. (2002) posit training and development programs are running as a part of strategic marketing and management perspectives, ensuring adaption to change. Training should be linked to business strategy to meet the competition. Human resources activities like acquisition, development, utilization, and human resources maintenance give an organization a competitive edge.

It is necessary not to overlook the predominant signs of awareness development in the corporate world in the last decade (Appelbaum \& Armstrong, 2003). This development was brought not only by technical advances or a combination of production factors but also by increased human resources efforts. Therefore, every organization's responsibility to enhance the workers' job performance and certainly implement training and development is one of the main steps that organizations need to do this (Black \& lynch, 1996). An organization's fundamental strength comes from its staff. Employees rely on supervisors, and the company relies on them all for their performance. Many researchers conclude that to retain a competitive edge, they must improve performance through a learning process.

Akala (2012) contended that training is critical to employee growth. Human resource activities such as job planning, coaching, mentoring, counseling, and general career growth help employees gain expertise that promotes and remains marketable for work opportunities. Employability requires abilities, expertise, and skills that improve the ability of workers to get and continue his career, to develop his skills to deliver services required, and to adapt to change, to make saleable always in the job markets when he has been fired from the previous jobs during the various periods of their life cycle (Franz \& Omolo, 2014). High-quality staff brings a company, even in the same market, a competitive advantage over others. Training needs assessment, and training goals should be identified for designing a training program to organize (Dessler, 2011). Training is helpful for both the employees and the employer. Employees can promote themselves, better themselves, increase job satisfaction, experience new skills, and embrace change (Ongori \& Nzonzo, 2011).

\section{Literature Review and Theoretical Framework}

Training needs assessment defines what types of training and competencies are required for employees to perform the desired task. Evaluation of training needs helps to identify 
performance standards and the knowledge, talents, and abilities needed by a company's staff to meet the requirements (Nyongesa, Nyamanga, \& Syanda, 2014).

Mode of training involves providing training to the employee in which settings - training while working on the job or training out of a job. There are two primary forms of training, in particular, on-the-job training and off-the-job training. New and other workers who lack experience are subject to job training at a specified workplace location. A type of learning administered away from the workplace is off-the-job training. It is proactive because of the essence of seasoned engagement and participation. This encourages simulation and role-playing (Ongori \& Nzonzo, 2011).

Employee commitment and participation are the most important factors to increase organizational performance. Training perceived by the employees to be effective will probably positively affect job satisfaction, commitment, and motivation (Ameeq \& Hanif, 2013). Policy on training and development plays an important role in managing human resources and leads to increased strategic alignment, staff commitment, flexibility, and efficiency.

Different theories are proposed in an employee training context. These are reinforcement theory (Skinner, 2014), Social learning theory (Bandura, 1969), Goal setting theory (Locke \& Latham, 1990), and adult learning theory (Knowles, 1980). Skinner (2014) states in 'reinforcement theory' that people's past behavior is key to perform the task. Positive and negative reinforcement provide people to do or not to the task. Positive reinforcement means people want to gain the knowledge, skills, and competency they want to acquire. Positive reinforcement is used to apply to get expected responses, while negative reinforcement is used to stop unexpected responses.Social learning theory posits people to learn from other's behavior (Bandura, 1969). People get knowledge and new skills from direct experiences or observe other behaviors. Computer-based learning technology enhances people to learn new computer skills and techniques to perform the tasks digitally. Job rotation is done to learn new skills (Dessler \& Varkkey, 2009). Simulation, Apprenticeship, role-playing is a new technology used in organizations to deliver skills through observation or direct experience (Bell \& Kozlowski, 2008; Karwowski \& Soszynski, 2008).

The goal-setting theory says behavior results from people's conscious goals and intentions. People's behavior is manipulated by their goals that make people deploy resources to achieve these goals. People are motivated highly when goals are challenging (Locke \& Latham, 1990) than mere an easy task. Employee commitment is a must for attaining the goals (Locke \& Latham, 1990). It is the degree of determination about achieving the accepted goal. It is the continuum of objectives, feedback, and employee's 
active participation to form employee motivation (Locke, \& Latham, 1990). Goals should be SMART that means specific, measurable, attainable, realistic and time targeted associated with goals. Training feedback gives an employee that their work is measured correctly, and suggestions are given for improving the weaknesses.

Adult learning theory suggests how an adult learns through pedagogy (Knowles, 1980). Two types of learning modules are suggested - Pedagogy and Andragogy. The pedagogy mode of learning is for youth and children. It gives clear instructions to the learner for deciding during training time. Andragogy is made for adult learning. The theory was developed by Knowles (1980) out of the specific theory of how adults learn. The most popular mode of learning has been for youth and children (Pedagogy). Pedagogy gives the instructor a significant responsibility for making decisions about learning content, method, and evaluation. Andragogy gives instructions on how to perform the task and make decisions for the adult learner.

Mohamud (2014) studied the training influence on organization commitment and retention towards the employee's performance. This research confirmed that training has a strong relationship between retention, performance, and organizational commitment. Purohit (2012) concluded that training helps employees better understand the job area, which will enhance their stock of knowledge. Extensive training providing continuous development, such as on-the-job training, training programs, and workshops, can be a driving factor for the firm's activities.

Ramakrishna, Kumar, Girdhar, and Krishnudu (2012) found the employees have attended more training and development programs, employees strongly agreed about the necessity of training and development programs. Sthapit (2012) pointed out induction training as the most effective in learning and least effective on behavior change criteria. Ongori and Nzonzo (2011) found that training plays an important role in employee performance. Through training, skills and knowledge are passed from the trainer to the trainee, especially on new products/services and technology. The training programs are useful for the employees to develop their skills and ability to perform the work and increase productivity.

Many kinds of literature are evident in Nepalese academia. Gautam (2012) studied on changing perspectives of managing human resources in Nepal and found organizations are not interested in funding for training and development programs. However, they understand the value of training in increasing communication and interpersonal skills, professional and vocational development, and leadership competencies. Gautam (2012) indicated that employee commitment distinguishes a successful organization from the rest. 
Pantha (2020) studied employee job satisfaction in Nepal's banking sector and found employees' working life, work environment; promotion and reward, recognition, training and development, and job security are studied as the major factors influencing employee satisfaction. Dangol (2020) measured motivational factors that aided in an upsurge of employee performance and revealed a positive and significant relationship between goalsetting, recognition programs, and training. KC and Neupane (2020) highlighted that banks provide workers with different training related to capacity building for their empowerment. The employee empowerment status is not adequate from the employees' viewpoint in the Nepalese commercial banking sector. Similarly, Gautam and Poudyal (2018) conducted a research on HR planning, selection, and training practices of Nepalese Pharmaceutical companies of Nepal and found the average level of practicing in human resource activities. Gautam (2018) assessed that the Nepalese banking sector's training culture status found that training culture is necessary for sustainable growth.

Recent investigations have demonstrated the importance of training in organizational settings. There is also a lack of research on employee commitment and employee performance through the initiation of training and development programs. Here, the researcher investigates the phenomenon further to measure training, employee commitment, and employee performance in the Nepalese Banking Sector. The research basically aims to;

- measure the impact of training need assessment on employee commitment;

- $\quad$ examine the impact of mode of training on employee commitment;

- $\quad$ analyze the impact of training duration on employee commitment;

- $\quad$ assess the impact of training feedback on employee commitment; and

- $\quad$ analyze the impact of employee commitment on employee performance.

\section{Research Framework}

The research framework of this research is shown in Figure1.

Independent Variables:

- Training Need Assessment

- Mode of Training

- Training Duration

Dependent Variable:

- Training Feedback

- Employee Performance

Figure1. Research Framework 


\section{Development of Hypothesis}

The proposed hypothesis for this study is listed here as,

$\mathrm{H} 1$ : Training need assessment has a significant impact on employee commitment.

$\mathrm{H} 2$ : Mode of training has a significant impact on employee commitment.

H3: Training duration has a significant impact on employee commitment.

H4: Training feedback has a significant impact on employee commitment.

H5: Employee performance has a significant impact on employee commitment.

In the course of this research work, limitations were encountered. This study focuses on training, employee engagement, and employee performance, but the other aspect of human resource management is not addressed. This research is limited to the commercial banks in the Kathmandu Valley, so it does not generalize the general employee's views who work beyond the Kathmandu Valley. For analysis, primary data were used. The researcher picked judgmental samples.

\section{Research Methods}

This research uses descriptive and causal research design to achieve the proposed objectives and test the hypotheses. The population of the study was employees in all commercial banks in Kathmandu Valley. Two hundred sixty-five samples were collected from different commercial bank employees in the Kathmandu Valley. Non-random sampling method was used, and judgmental sampling was applied as the employees are found during office hours for a particular day is included in the research also must have at least one training involvement. Structured questionnaires were used. Questionnaires were based on a Likert Scale indicating "1-Strongly Disagree" to "5-Strongly Agree". The researcher has gone to different commercial bank branches and requested employees who were present during the office hour and distribute them to fill the questionnaires and collect the same or another day.

With the aid of SPSS tools, the final performance of the demographic data analysis is obtained. For psychometric and econometric aspects of the model, partial least square structural equation modeling is performed with Smart PLS 3.0 using 5000 resamplings bootstrapping (Hair, Hult, Ringle, \& Sarstedt, 2013).

Male respondents are 53 percent, and female respondents are 47 percent. Most of the respondents are aged below 30 years showing 45 percent, followed by 30 to 40 years by 30 percent. Seventy percent of the respondent are graduates or above qualification. Sixty-five percent of employees have a job experienced below five years, 22 percent having job experience between 5-10 years. 


\section{Results and Discussion}

\section{Measurement Model}

Table 1

Evaluation of the Outer or Measurement Model

\begin{tabular}{|c|c|c|c|c|c|c|}
\hline Constructs & Items & Loadings & $\begin{array}{l}\text { Cronbach's } \\
\text { Alpha }\end{array}$ & rho_A & $\mathrm{CR}$ & AVE \\
\hline \multirow{4}{*}{$\begin{array}{l}\text { Employee } \\
\text { Commitment }\end{array}$} & $\mathrm{EC} 2$ & 0.705 & \multirow{4}{*}{0.755} & \multirow{4}{*}{0.755} & \multirow{4}{*}{0.85} & \multirow{4}{*}{0.58} \\
\hline & EC5 & 0.762 & & & & \\
\hline & EC6 & 0.801 & & & & \\
\hline & EC7 & 0.77 & & & & \\
\hline \multirow{4}{*}{$\begin{array}{l}\text { Employee } \\
\text { Performance }\end{array}$} & EP1 & 0.714 & \multirow{4}{*}{0.761} & \multirow{4}{*}{0.771} & \multirow{4}{*}{0.85} & \multirow{4}{*}{0.58} \\
\hline & EP2 & 0.745 & & & & \\
\hline & EP4 & 0.79 & & & & \\
\hline & EP5 & 0.794 & & & & \\
\hline \multirow{2}{*}{$\begin{array}{l}\text { Mode of } \\
\text { Training }\end{array}$} & MOT1 & 0.833 & \multirow{2}{*}{0.711} & \multirow{2}{*}{0.742} & \multirow{2}{*}{0.78} & \multirow{2}{*}{0.64} \\
\hline & MOT4 & 0.764 & & & & \\
\hline \multirow{3}{*}{$\begin{array}{l}\text { Training } \\
\text { Duration }\end{array}$} & TD1 & 0.753 & \multirow{3}{*}{0.747} & \multirow{3}{*}{0.719} & \multirow{3}{*}{0.81} & \multirow{3}{*}{0.58} \\
\hline & TD2 & 0.791 & & & & \\
\hline & TD4 & 0.744 & & & & \\
\hline \multirow{3}{*}{$\begin{array}{l}\text { Training } \\
\text { Feedback }\end{array}$} & TF1 & 0.719 & \multirow{3}{*}{0.778} & \multirow{3}{*}{0.778} & \multirow{3}{*}{0.78} & \multirow{3}{*}{0.54} \\
\hline & TF4 & 0.734 & & & & \\
\hline & TF5 & 0.755 & & & & \\
\hline \multirow{3}{*}{$\begin{array}{l}\text { Training Need } \\
\text { Assessment }\end{array}$} & TNA2 & 0.792 & \multirow{3}{*}{0.713} & \multirow{3}{*}{0.712} & \multirow{3}{*}{0.84} & \multirow{3}{*}{0.63} \\
\hline & TNA3 & 0.769 & & & & \\
\hline & TNA4 & 0.826 & & & & \\
\hline
\end{tabular}

Testing measurement model, internal reliability, convergent validity, and discriminant validity techniques were used (Hair, Sarstedt, Ringle, \& Mena, 2012). The loading of each indicator items was above 0.7, composite reliability (CR) Dijkstra and Henseler's rho_A of each construct is greater than 0.70 (Ali, Rasoolimanesh, Sarstedt, Ringle, \& Ryu, 2018; Fornell \& Larcker, 1981; Hair, Hult, Ringle, \& Sarstedt, 2017; Hair, Matthew \& Christian, 2020). The value of rho_A is gaining more importance these days than Cronbach's Alpha (Hair et al., 2020). The average variance extracted (AVE) score is greater than 0.5 for all the constructs in this research, so convergent validity is obtained. 


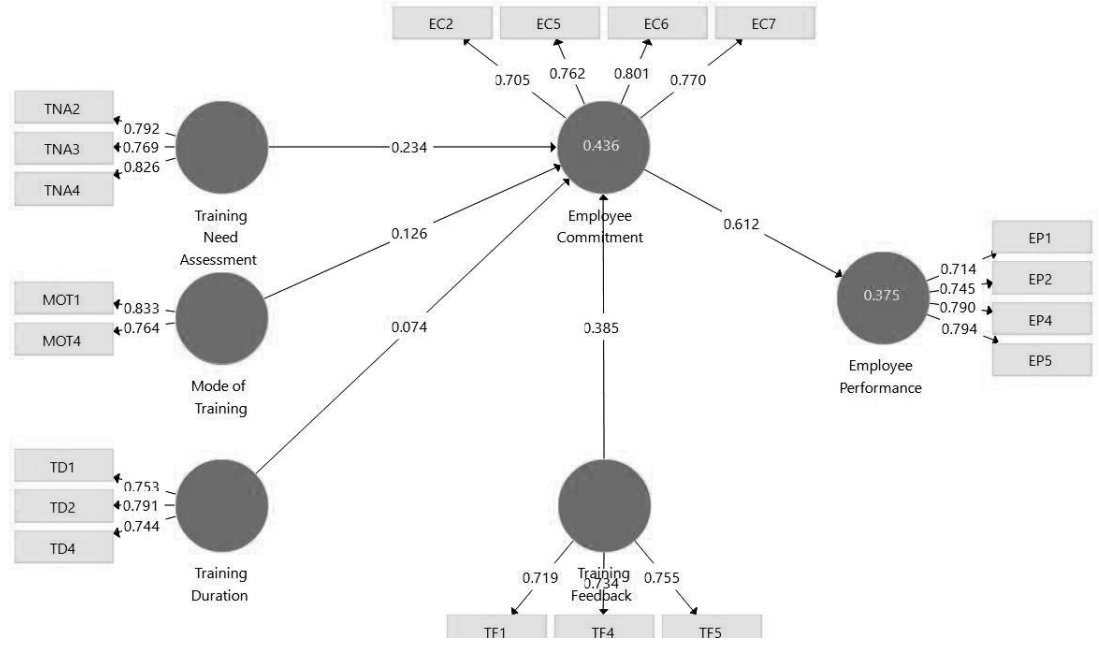

Figure 2. Measurement model showing indicators, path and coefficient of determination $\left(\mathrm{R}^{2}\right)$

Figure 2 shows the coefficient of determination value for the proposed model. The coefficient of determination value for Employee Commitment (EC) is 0.436 or 43.6 percent, and employee performance (EP) is 0.375 or 37.5 percent. The effect of predictor variables training need assessment (TNA), mode of training (MOT), training duration (TD), and training feedback (TF) has an influence on employee commitment (EC) by 43.6 percent. Similarly, employee commitment (EC) influences employee performance (EP) by 37.5 percent.

To check discriminating validity, Fornell, and Larcker Criterion (1981) are also helpful. The diagonal line shows the square root of AVEs of the construct and must be higher than the correlation values of rows and columns between objects (Henseler, Ringle, \& Sarstedt, 2015). It is illustrated in Table 2.

Table 2 shows that the average square root variance obtained from each diagonal line construct (bold) is greater than its correlation with the other constructs, thereby confirming the validity of discriminating and separating each construct from each other (Fornell \& Larcker, 1981). The analysis is suitable for final evaluation (Henseler et al., 2015). 
Table 2

Discriminant Validity (Fornell and Larcker Criterion, 1981)

\begin{tabular}{|c|c|c|c|c|c|c|}
\hline Constructs & 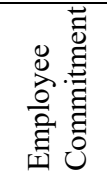 & 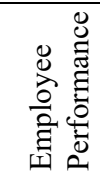 & 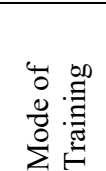 & 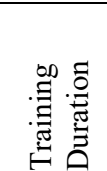 & 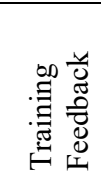 & 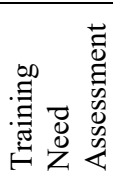 \\
\hline $\begin{array}{l}\text { Employee } \\
\text { Commitment }\end{array}$ & 0.76 & & & & & \\
\hline $\begin{array}{l}\text { Employee } \\
\text { Performance }\end{array}$ & 0.612 & 0.762 & & & & \\
\hline $\begin{array}{l}\text { Mode of } \\
\text { Training }\end{array}$ & 0.451 & 0.441 & 0.799 & & & \\
\hline $\begin{array}{l}\text { Training } \\
\text { Duration }\end{array}$ & 0.365 & 0.318 & 0.315 & 0.763 & & \\
\hline $\begin{array}{l}\text { Training } \\
\text { Feedback }\end{array}$ & 0.598 & 0.5 & 0.46 & 0.466 & 0.736 & \\
\hline $\begin{array}{l}\text { Training Need } \\
\text { Assessment }\end{array}$ & 0.52 & 0.493 & 0.528 & 0.304 & 0.511 & 0.796 \\
\hline
\end{tabular}

Table 3

HTMT

\begin{tabular}{|c|c|c|c|c|c|c|}
\hline Constructs & 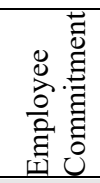 & 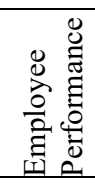 & 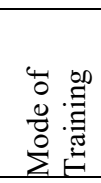 & 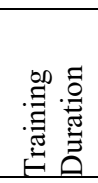 &  & 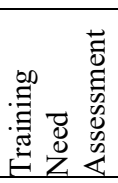 \\
\hline \multicolumn{7}{|l|}{$\begin{array}{l}\text { Employee } \\
\text { Commitment }\end{array}$} \\
\hline $\begin{array}{l}\text { Employee } \\
\text { Performance }\end{array}$ & 0.796 & & & & & \\
\hline $\begin{array}{l}\text { Mode of } \\
\text { Training }\end{array}$ & 0.78 & 0.755 & & & & \\
\hline $\begin{array}{l}\text { Training } \\
\text { Duration }\end{array}$ & 0.512 & 0.448 & 0.576 & & & \\
\hline $\begin{array}{l}\text { Training } \\
\text { Feedback }\end{array}$ & 0.894 & 0.752 & 0.856 & 0.754 & & \\
\hline $\begin{array}{l}\text { Training Need } \\
\text { Assessment }\end{array}$ & 0.709 & 0.672 & 0.847 & 0.424 & 0.796 & \\
\hline
\end{tabular}


The ratio of average indicator correlations between constructs is determined by Heterotrait-Monotrait (HTMT), split by indicator correlations within the same construct (Henseler et al., 2015). A maximum 0.9 threshold is suggested in the literature (Hair et al., 2017; Henseler et al., 2015; Henseler, Ringle \& Sinkovics, 2009).

The HTMT matrix in which values below 0.9 indicate sufficient discriminant validity is highlighted in Table 3 (Hair et al., 2017; Henseler et al., 2015; Henseler et al., 2009). Both constructs are below the threshold and thus show ample validity of discriminants.

\section{Structural Model}

The structural model assesses the path coefficient relationship between training need assessment, mode of training, training duration, training feedback, employee commitment, and employee performance constructs. Hypotheses were tested using the bootstrapping method to 5000 resamples at a 5 percent level of significance.

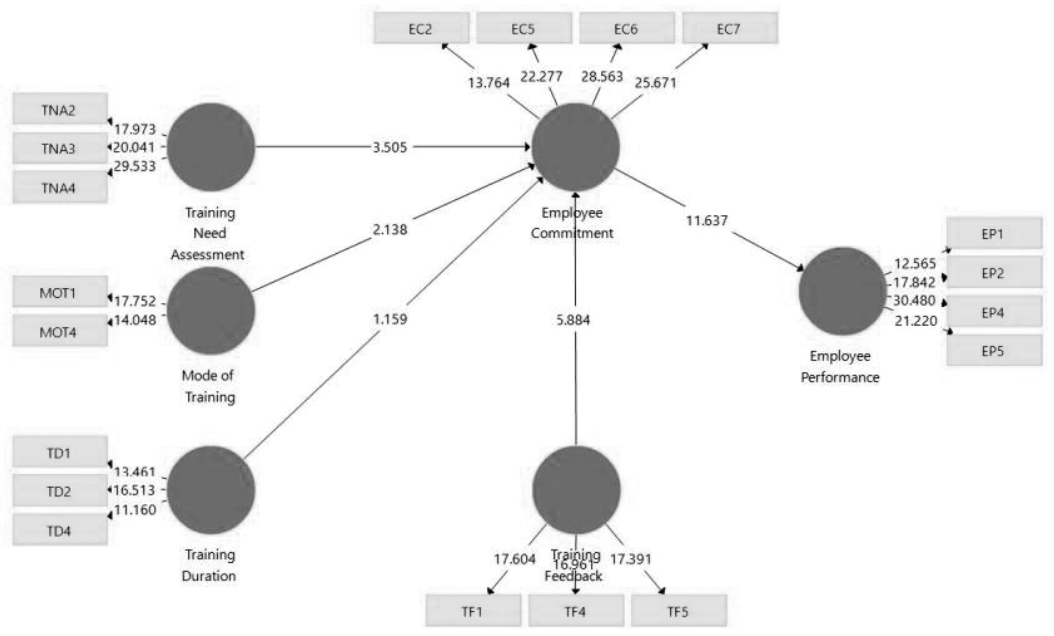

Figure 3. Structural model

Figure 3 shows the indicator items and path coefficients on t-values. The relationships between endogenous and exogenous constructs were tested at the 5 percent significance level using the path coefficient $(\beta)$ and t-statistics values greater than 1.96 (Hair et al., 2012). The $R^{2}$ value was used to determine the proportion of the variance represented by the exogenous constructs in the structural model (Henseler et al., 2015). The hypothesis is shown in Table 4. 
Table 4 highlights the PLS-SEM measurement of the structural models revealed that training need assessment $(\beta=0.236, t=3.505$, $p$-value $=0.000<0.05)$, mode of training $(\beta=0.125, \mathrm{t}=2.138, \mathrm{p}$-value $=0.033<0.05)$, and training feedback $(\beta=0.386, \mathrm{t}=5.884, \mathrm{p}$ value $=0.000<0.05)$, have a positive impact on employee commitment, hence giving significant assurance for the acceptance of $\mathrm{H} 1, \mathrm{H} 2$ and $\mathrm{H} 4$. The relationship between employee commitment and employee performance $(\beta=0.614, \mathrm{t}=11.637$, $\mathrm{p}$-value $=0.000<$ 0.05 ) were significant at 5 percent level of significance. Thus, H5 was accepted. But the relationship between training duration and employee commitment $(\beta=0.072, \mathrm{t}=1.159$, $\mathrm{p}$ value $=0.246>0.05$ ) was not significant at $5 \%$ level of significance. So, H3 is not supported. As presented in the measurement model (Shown as Figure2), the $\mathrm{R}^{2}$ value of 0.436 and 0.375 indicates that $43.6 \%$ and $35.5 \%$ variance in the endogenous variables, that is, its training predictors explain employee commitment - training need assessment, mode of training, training duration and training feedback, respectively. The PLS-SEM results that the tested model has a moderate degree of predictive quality and precision (Chin, 1998; Hair, Ringle, \& Sarstedt, 2011; Henseler et al., 2015).

Table 4

Hypothesis Testing

\begin{tabular}{lcccc}
\hline Hypothesis & Path & t-value & p-value & Decision \\
\hline $\begin{array}{l}\text { H1: Training Need Assessment -> } \\
\text { Employee Commitment }\end{array}$ & 0.236 & 3.505 & 0 & Supported \\
$\begin{array}{l}\text { H2: Mode of Training -> Employee } \\
\text { Commitment }\end{array}$ & 0.125 & 2.138 & 0.033 & Supported \\
$\begin{array}{l}\text { H3: Training Duration -> Employee } \\
\text { Commitment }\end{array}$ & 0.072 & 1.159 & 0.246 & $\begin{array}{l}\text { Not } \\
\text { Supported }\end{array}$ \\
$\begin{array}{l}\text { H4: Training Feedback -> Employee } \\
\text { Commitment }\end{array}$ & 0.386 & 5.884 & 0 & Supported \\
$\begin{array}{l}\text { H5: Employee Commitment -> } \\
\text { Employee Performance }\end{array}$ & 0.614 & 11.637 & 0 & Supported \\
\hline
\end{tabular}

\section{Discussion and Conclusion}

The study's purpose was to examine the nexus of training, employee commitment, and employee performance in the Nepalese commercial banking sector. This research confirmed that training need assessment, mode of training, and training feedback increase employee commitment in the commercial banking sector. Of the four training constructs measured in this study, training need assessment, mode of training, and 
training feedback influence employee commitment. Training provides skills and capacity for employee commitment to performance (Ongori \& Nzonzo, 2011; Purohit, 2012; Dangol, 2020; Pantha, 2020; KC \& Neupane, 2020). Job training, training programs, and workshops enhance employee performance (Purohit, 2012; Sthapit, 2012).

Also, employee commitment is the predecessor to employee performance. This finding is aligned with Mohamud (2014) and Gautam (2012) that the organizational commitment and employee performance have been linked together. The banking sector must empower its employees through training and management development programs to increase employee commitment, leading to better employee performance.

\section{References}

Akala, H. S. (2012). Factors influencing employee retention among the non-teaching staff at the University of Nairobi (Master Dissertation). University of Nairobi, Nairobi.

Ali, F., Rasoolimanesh, S. M., Sarstedt, M., Ringle, C. M., \& Ryu, K. (2018). An assessment of the use of partial least squares structural equation modeling (PLS-SEM) in hospitality research. International Journal of Contemporary Hospitality Management, 30(1), 514-538.

Ameeq, A., \& Hanif, F. (2013). Impact of training on employee's development and performance in Hotel Industry of Lahore, Pakistan. Journal of Business Studies Quarterly, 4(4), 68-82.

Appelbaum, M., \& Armstrong, S. (2003). Stress free performance appraisal. USA: Career Press Publications.

Bandura, A. (1969). Social-learning theory of identificatory processes. In D. Goslin (Ed.), Handbook of Socialization Theory and Research. 213-262. Chicago: Rand McNally.

Bell, S., \& Kozlowski, J. (2008). Active learning: Effects of core training design elements on self-regulatory processes, learning and adaptability. Journal of Applied Psychology, 93(2), 296-316.

Black, S. E., \& Lynch, L. M. (1996). Human-capital investments and productivity. The American Economic Review, 86(2), 263-267.

Chin, W. W. (1998). Issues and opinion on structural equation modeling. MIS Quarterly, 22(1), 7-16.

Dangol, P. (2020). An analysis of motivational factors affecting employee performance. Journal of Business and Social Sciences Research. 5(1), 63-74.

Dessler, G. (2011). A framework for human resource management (6th ed.). Upper Saddle River, NJ: Prentice-Hall. 
Dessler, G., \& Varkkey, B. (2009). Human resource management. New Delhi: Dorling Kindersley (India) Pvt. Ltd..

Elanga, A., \& Imran, A. (2013). The effect of training on employee performance. European Journal of Business and Management, 4, 137-147.

Evans, P., Pucik V., \& Barsoux, J. L. (2002). The Global challenge: Framework for international human resource management. Boston: McGraw-Hill.

Fornell, C., \& Larcker, D. F. (1981). Evaluating structural equation models with unobservable variables and measurement error. Journal of Marketing Research, $18(1), 39-50$.

Franz, J., \& Omolo, J. (2014). Youth employment initiatives in Kenya: A report of review commissioned by the World Bank and Kenya Vision 2030. Nairobi: World Bank.

Gautam, D. K. (2012). Changing perspectives of managing human resources in Nepal. Asia Pacific Journal of Business, 3(2), 23-33.

Gautam, P. (2018). Training culture and employees performance in Nepali Banking Industry. The International Research Journal of Management Science, 3(1), 6480.

Gautam, T. P., \& Poudyal, S. R. (2018). Human resource planning, selection and training practices of Nepalese pharmaceutical companies of Nepal. Nepal Journal of Multidisciplinary Research (NJMR), 1(1), 58-70.

Hair, J. F., Hult, G. T. M., Ringle, C., \& Sarstedt, M. (2013). A primer on partial least squares structural equation modelling (PLS-SEM). Los Angeles: Sage Publications.

Hair, J. F., Hult, G. T. M., Ringle, C., \& Sarstedt, M. (2017). A primer on partial least squares structural equation modeling (PLS-SEM) (2nd ed.). Thousand Oaks, California: Sage Publications Limited Inc..

Hair, J. F., Matthew, H., \& Christian, N. (2020). Assessing measurement model quality in PLS-SEM using confirmatory composite analysis. Journal of Business Research, 109, 101-110.

Hair, J. F., Ringle, C. M., \& Sarstedt, M. (2011). PLS-SEM: Indeed a silver bullet. Journal of Marketing Theory and Practice, 19(2), 139-152.

Hair, J. F., Sarstedt, M., Ringle, C. M., \& Mena, J. A. (2012). An assessment of the use of partial least squares structural equation modeling in marketing research. Journal of the Academy of Marketing Science, 40(3), 414-433.

Henseler, J., Ringle, C. M., \& Sinkovics, R. R. (2009). The use of partial least squares path modeling in international marketing. Advances in International Marketing, 20(1), 277-319. 
Henseler, J., Ringle, C. M., Sarstedt, M. (2015). A new criterion for assessing discriminant validity in variance-based structural equation modeling. Journal of Academy of Marketing Science, 41(1), 115-135.

Karwowski, M., \& Soszynski, M. (2008). How to develop creative imagination? Assumptions, aims and effectiveness of role play training in creativity (RPTC). Thinking Skill and Creativity Journal, 3(2), 163-171.

KC, R., \& Neupane, A. (2020). Exploring the status of employee empowerment in the commercial banking sectors in Nepal. International Journal of Scientific and Research Publications, 10(4), 340-349.

Knowles, M. S. (1980). The modern practice of adult education: From pedagogy to andragogy. Chicago: Follett.

Locke, E. A., \& Latham, G. P. (1990). A theory of goal setting and task performance. Englewood Cliffs, NJ: Prentice-Hall.

Mohamud, A. M. (2014). The effect of training on employee performance in public sector organization in Kenya: The case of Chif Machakos County (Doctoral Dissertation). University of Nairobi.

Nyongesa, W. W. B., Nyamanga, E. A., \& Syanda, P. (2014). Accessing the extent to which staff training needs are implemented at the Kenya Polytechnic University College. Journal of Education and Practice, 5(28), 212-231.

Ongori, H., \& Nzonzo, J. C. (2011). Training and development practices in an organization: An intervention to enhance organizational effectiveness. International Journal of Engineering and Management Sciences, 2(4), 187-198.

Pantha, S. (2020). A study on employee job satisfaction in the banking sector in Nepal (Thesis). Centria University of Applied Sciences.

Purohit, M. (2012). An evaluation of HRD practices followed in co-operative banks in Pune Region. ACADEMICIA: An International Multidisciplinary Research Journal, 2(8), 186-195.

Ramakrishna, G., Kumar, K., Girdhar, M., \& Krishnudu, C. H. (2012). Effectiveness of training and development programmes -A case study of Canara Bank employees in Kurnool District. International Journal of Multidisciplinary Research, 2(4), 150-162.

Salas, E., \& Cannon-Bowers, J. A. (2001). The science of training: A decade of progress. Annual Review of Psychology, 52, 471-499.

Skinner, B. (2014). Science and human behavior. London: Macmillan Press.

Sthapit, A. (2012). Strategic factors in evaluation of induction training effectiveness: An exploratory study of Nepali Bank Managers. International Journal of Multidisciplinary Management Studies, 2(8), 16-32. 